\title{
An Assessment Of Parental Involvement In Learner Retention In Public Primary Schools Of Malindi Sub - County In Kilifi County, Kenya
}

\author{
Josephine Kagwiria Kirimi \\ Daudi Muthoka Muteti \\ School of Education, Mount Kenya University
}

doi: 10.19044/esj.2016.v12n16p136 URL:http://dx.doi.org/10.19044/esj.2016.v12n16p136

\begin{abstract}
Despite the Kenya government re-introducing free primary education, some school age children are still locked out of school whereas dropout and repetition continue to be pervasive. The study found out that retention rates in public primary schools in central zone of Malindi sub-county, Kenya had declined and the dropout rate was on the increase. The most prominent causes of the declining rates of access and retention of pupils in public primary schools in the zone were, illiteracy, poverty, early pregnancy, grade repetition and tourism activities. The study recommends that the government enforce adherence of the laid down policies to enhance learner retention in education. The government should also put up adult education centres to help improve literacy levels among parents.
\end{abstract}

Keywords: Parental involvement, learner retention

\section{Introduction}

The importance of bringing about efficiency in the education sector is critical if the Education For All (EFA) goal of Universal Education is to be attained. The state's policies, guidelines and by-laws for the educational programs strongly influence parental involvement practised by schools (Theuri, 2004). The need for the effective involvement of parents in the education of their children over and above financial contributions in schools has largely been unrecognised in Kenya (Kimu, 2012). Given the benefits outlined above, effective parental involvement would be particularly a suitable means of improving education in a developing country like Kenya.

Kenya has provided for various roles that parents can play in education. The Education Act, 2008, provides for parents to be represented on the School Management Committee (SMC) (Republic of Kenya 2008). Institutional governance structures such as school committees, parent-teacher 
associations and school boards of management reflect the interests of all stakeholders served by the school. Only a few parents are legally involved in school management activities and their effective role has not been fully recognised. According to Kimu (2012) over the past years countries in sub Saharan Africa have abolished primary tuition fees and introduced Free Primary Education (FPE). In many parts, children are starting primary school in large numbers than ever before but dropout rates are significant and lead to low levels of primary school completion (Theuri, 2004). In Benin, for example the primary school completion rate in 2005 was $62 \%$, although it increased steadily from $38 \%$ in 2000 .

Despite a rapid increase in primary school enrollment following the Free Primary Education program, primary completion and progression rates have remained low. With Free Primary Education it was hoped that every Kenyan child would have access to basic education and that access and retention rates would improve. The declining enrollment rates and low retention rates is today being witnessed in some public primary schools, a conclusion that would be expected to be minimal with Free Primary Education (Ministry of Education, 2013).

Table 1 Malindi sub-county School Dropout rates (2008-2013)

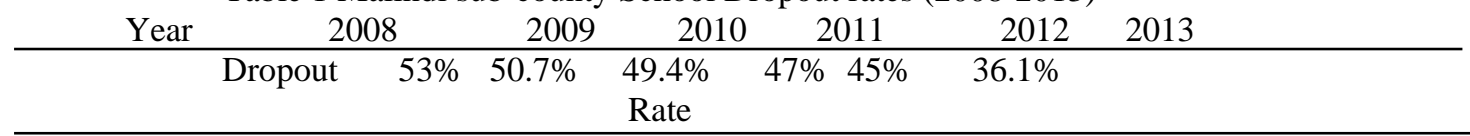

Source; Malindi Sub-county Education Subsector statistical return 8/2/2013

Table 1 shows the dropout rates in Malindi sub-county, Kenya from 2008-2013. Central zone is one of the zones in Malindi sub-county, Kenya where retention rates are low which prompted the researcher to investigate parental involvement in learner retention in the area.

\section{Literature Review}

\section{Parental Level of Income and Learner Retention}

Njeru and Orodho (2003), consent that the critical factors that are responsible for the low access and poor participation in education is poverty. High rates of poverty at household level have made poor households either not to enroll their children in primary schools or fail to sustain an uninterrupted participation of those who are enrolled due to inability to meet various requirements. This has resulted in inadequate provision of learning facilities to the enrolled, poor quality education and high dropout rates among the poor. According to Otunge (2004), large family size is quite strongly associated with socio-economic disadvantage. The large family size limits the parental involvement in the academic welfare of each child. Thus leads to low participation of the child in school activities and may eventually lead to dropout. The high poverty levels are experienced in Arid and Semi 
Arid Lands (ASAL) areas; education access in these areas is lower than in high potential areas (UNESCO, 2002). Poverty is thus addressed in two avenues, first inability to meet indirect costs for schooling such as school learning and teaching materials, uniforms, transport to and from school and food.

Several studies done in Malawi, Ghana, Zambia, Ethiopia and Tanzania have shown that children are hindered from effective participation and retention in schooling due to inability to afford such costs (Kelly 1999). In conformity with this situation, Mingat (2002) established that the richest households, $76 \%$ of their children attend school compared to $40 \%$ of the poorest households; this means that children from poor households have much lower attendance than those from richer households. Greg (2002) cited in Chipkenei, (2004) concur with Mingat (2002) that the level of income is the most powerful influence on primary school enrollment in developing countries. Onyango (2000) showed that parental social-economic background influences their children's participation and retention in education. This is especially so for the developing countries where children of poor families are not provided with adequate educational materials and most are not apt to enroll in school. If enrolled, they are likely to drop out of school than children who are from well off families. Briggs (1980) cited in Mbai (2004) contend that poor families may contemplate bearing the cost of sending their children to school but might abandon the whole exercise when more expenses are demanded.

A report carried out in contemporary economic policy magazine in January 2001 entitled Determinants of school enrollment on performance in Bulgaria revealed that the role of income among the poor and the rich is a major determinant for school access. Those poor families are constrained in their investment in education and withdraw from school prematurely. At home the child might not have appropriate facilities and resources to enable them carry on with school work. In some homes of the poor, there might be no table and chairs that can be used for reading, while light for night studies is either of very poor quality or non-existent thus the family environment is not conducive to learning (Kimu, 2012). Eventually the child becomes too frustrated to continue schooling under these hardship conditions.

\section{Parental Involvement and Learner Retention}

It is widely recognized that if pupils are to maximize their potential from schooling they will need the full support of their parents. Attempts to enhance parental involvement in education occupy governments, administrators, educators and parents organizations (Desforges, 2003). Lemmer, (2007) cites the frequency of parent-teacher contact as influencing the involvement of learners in learning and thereby improves their retention 
in school. Parental education is positively related to parent-teacher contact. The more educated the parent, the greater is their involvement in their child's education (Kgaffe, 2001). Parental involvement is also positively related to primary school learners' academic achievement; time spent on homework, favorable attitudes towards school and reduced levels of primary school dropout. Parents who attend parent-teacher conferences, open houses, or other school activities show how important their children are to them (Suresh, 2010). This support is especially vital to adolescents who are particularly at risk of disengaging from school.

The United States department of education (2010) concluded that poverty is an important factor accounting for differences in performance and retention across rural and urban areas. The studies show that poverty alone does not account for all the difference in the performance and retention of the student. Johnson, 2006 (as cited in Muhammed \& Akanle, 2008), opined that poverty of the parents has elastic effects on their children academic works as they lack enough resources and funds to sponsor their education and good school, good housing facilities and medical care and social welfare services. Gordon \& Lance (2005), observed that children growing up in poor families are likely to have home environments or face other challenges which would continue to affect development even if family income rose substantially. They also said that for children growing up in poor families, extra income does appear to have a positive causal effect.

Susan (2010), notes that children of affluent parents are more likely to succeed in life than the children of poor parents. For instance compared to more affluent children, poor children score lower on tests of cognitive skill in early childhood. Children who have more behaviour problems in school and at home, are more likely to drop from school, have children at a younger age, and are more likely to be poor themselves when they are adults. The most initiative explanation for this difference is that rich parents can spend more than poor parents on their children and that these 'investments' lead to better outcomes for their children. The researcher further established that if poor children fail because their parents cannot make sufficient monetary investments in their future, then government can improve the life chances of poor children by providing families with the means to make the investment or by providing the investments directly in the form of schooling, health care and other human capital inputs. Greg, (2008) states that family income has substantial but decidedly selective associations with children's retention in primary school. The level of family income is one of the most powerful influences on demand for primary and secondary and even higher education enrollment rates in developing countries (Susan, 2010). Income of the parent influences students' retention because it determines the availability of education material or lack of it and availability of school fees or lack of it. 
Onsomu et al., (2004) observes that the Kenyan educational policy advocates for parental involvement, although its emphasis is mainly on better quality teaching and greater administrative efficiency. In public schools, community involvement in the financing and management of schools takes the form of participation in school management committees. This includes Parent Associations (PA) in primary schools and Boards of Management (BOM) in secondary school. Such bodies involving parents mainly fulfill the function of funding, management and operation of schools through the provision of teaching/learning materials. Through legislation, the Kenyan government provides for the democratic management of primary schools by the stakeholders, involving the school managers, parents and the community in schools (Republic of Kenya, 2001). This implies the creation of an environment conducive to parental involvement in schools.

\section{Methodology}

The researcher adopted a survey research design. This design is descriptive in nature. Descriptive research is used to obtain information concerning the current status of the phenomena and to describe "what exists" with respect to variables or conditions in a situation (Kaleen\& Ahmad, 2008). The descriptive research design enabled the researcher to use both qualitative and quantitative methods in collecting data especially from the administrators in primary schools as well as other stakeholders. According to Orodho (2009), survey design is the most frequently used method for collecting information about peoples' attitudes, opinions, habits or any of the variety of education or social issues. The design is in agreement with the views of Kothari (2004) who contend that it is used to assess attitudes and opinions about events, individuals or procedures.

\section{Results and discussion}

\section{Demographic Characteristics of Respondents}

The study collected data from 5 schools. All the 5 head teachers and 43 class teachers participated in the study, while 18 PA executive members and 470 parents took part in the study. In total 317 out of 390 respondents participated in the study and was considered suitable enough to give a true reflection of the issues under study. This is shown in table 1 below.

Table 1. Response rate

\begin{tabular}{lcll}
\hline Category & Frequency & Percentage & Mean \\
\hline Head teachers & 5 & 1 & \\
Class teachers & 43 & 11 & \\
Executive PA & 18 & 5 & 20 \\
Parents & 324 & 83 & \\
Total & 390 & 100 & \\
\hline
\end{tabular}




\section{Response by Gender}

The response rate by gender indicated that $48 \%$ of the respondents were males while 52\% were females. The high percent response by women can be atrributed to the fact that some of the parents were single mothers while some men could not be reached because they work far from their homes leaving the wives behind. This is summarised in figure 1

Figure 1 Response by gender

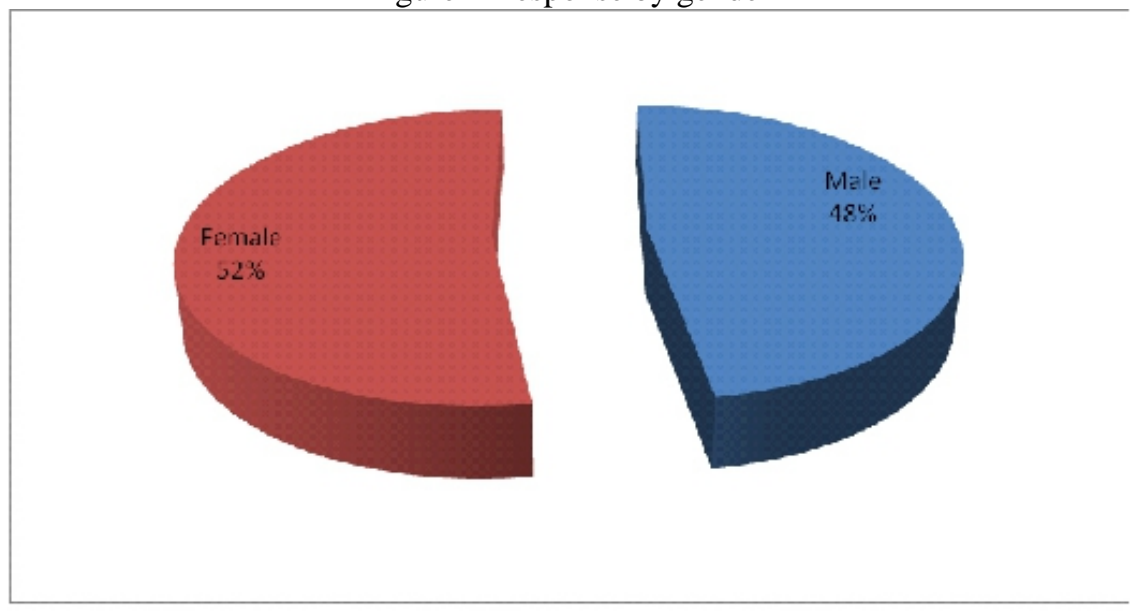

Source: Survey Data (2015)

\section{Age}

In terms of their age, $1 \%$ were below 30 years, $24 \%$ were $31-40$, $61 \%$ were $41-50$ years and $14 \%$ were above 50 years as shown in Table 2 . Majority of the respondents were above age 40 which implies that majority of them were experienced in matters concerning child learning. This observation is attributed to the departure from extended families where young parents are common to nuclear families where one has to be economically stable before starting a family.

\begin{tabular}{llcrl}
\multicolumn{2}{c}{ Age group } & $\begin{array}{c}\text { Table 2 Age Distribution } \\
\text { Frequency }\end{array}$ & Percent & Mean \\
\hline \multirow{4}{*}{ Total } & Below 30 yrs & 3 & 1 & \\
& 31-40 yrs & 73 & 24 & \\
& $41-50$ yrs & 181 & 61 & \\
& Above 50yrs & 42 & 14 & \multirow{2}{*}{40.5} \\
& & 299 & 100 & \\
\hline \hline
\end{tabular}

\section{Education level}

In regard to their education level Table 3 shows that the majority of parents had a diploma level of education $27 \%$ and below, $15 \%$ were P1, $14 \%$ were secondary school leavers, $19 \%$ primary school graduates, another 
$10 \%$ were degree holders, 9\% had Masters while the remaining 6\% were holders of doctoral degrees. Majority of the secondary and primary graduates did not have permanent jobs. This can be attributed to the lack of necessary skills required in any form of employment. Most of them have basic education and lack any specialized form of training.

Table 3 Education distribution

Education level Frequency

Percent

Mode

\begin{tabular}{lccl}
\hline PhD & 18 & 6 & \\
Masters & 27 & 9 & \\
Degree & 30 & 10 & \\
Diploma & 81 & 27 & \\
P1 & 46 & 15 & 81 \\
Secondary & 41 & 14 & \\
Primary & 56 & 19 & 100 \\
Total & 299 & Source: Survey Data (2015) \\
\hline
\end{tabular}

\section{Occupation}

The occupation distribution of the respondents was determined. Figure 2 indicate that 71 (24\%) of the respondents are permanently employed, 103(34\%) are self employed while 125(42\%) are casuals. The results show that the majority of the repondents are casuals. This can be attributed to low literacy levels and negative attitudes to agriculture due to the negative impacts of climate change brought about about by global warming that have made agriculture a very unpridictable occupation.

Figure 2 Occupation Distribution

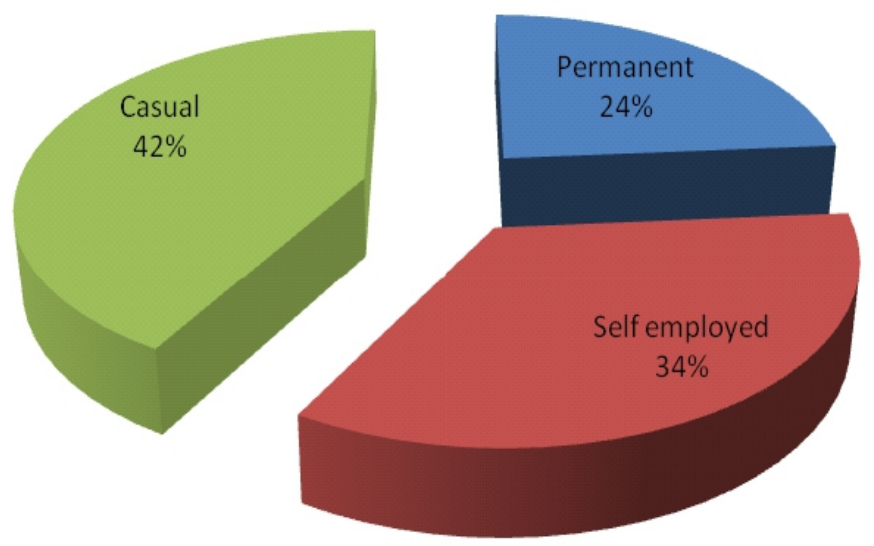

Source: Survey Data (2015) 


\section{Income level}

As shown in table 4 a majority of the respondents 109 (37\%) earned an average salary of between Ksh. 10001-30000, another 97 (32\%) earned a salary of less Ksh.10000 while the remaining 93 (31\%) earned a salary well above Ksh.30000.

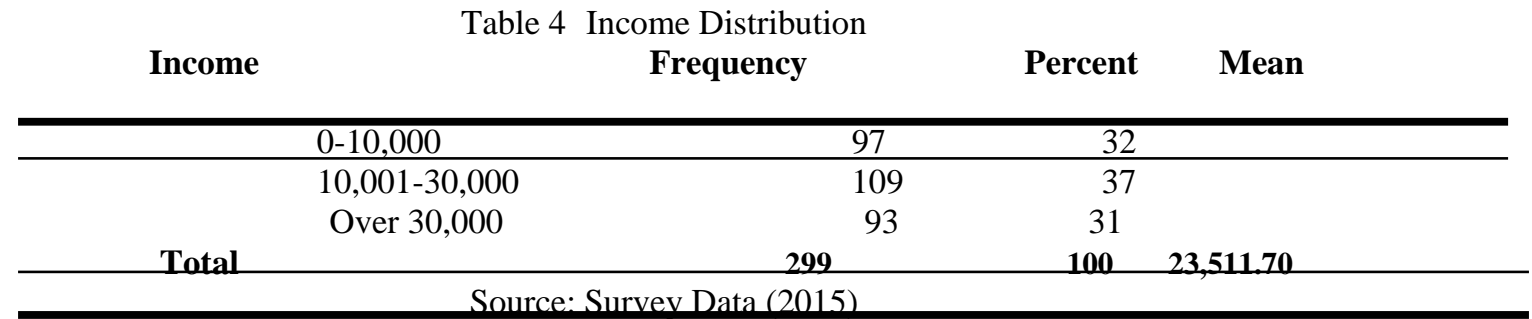

\section{Family Size}

The family sizes of the respondents were analysed and summarised in table 5. This shows that $15 \%$ of the respondents had between $1-2$ children, $25 \%$ had a family size of 3-4 children, 33\% had a family size of 5-7 children and the remaining $27 \%$ had family sizes of $7-8$ children. Majority of the repondents had family sizes of 5-6 children and on average each family had 5 children.

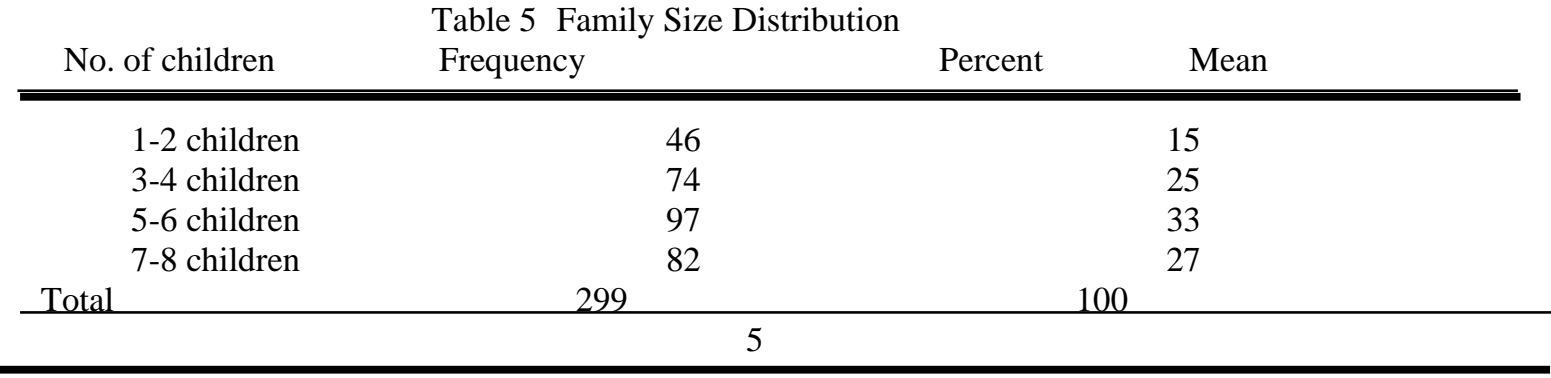

Source: Survey Data (2015)

\section{Payment of extra levies not funded by Government}

The research also sought to know whether the respondents paid extra levies not paid by the government in good time. The results were summarised in figure 3. A majority of the rspondents 223 (75\%) did pay in good time while the rest 76 (25\%) did not pay in good time leading to their children being sent home many a times to collect the money. 
Figure 3 Payment extra leavies not funded by the Government

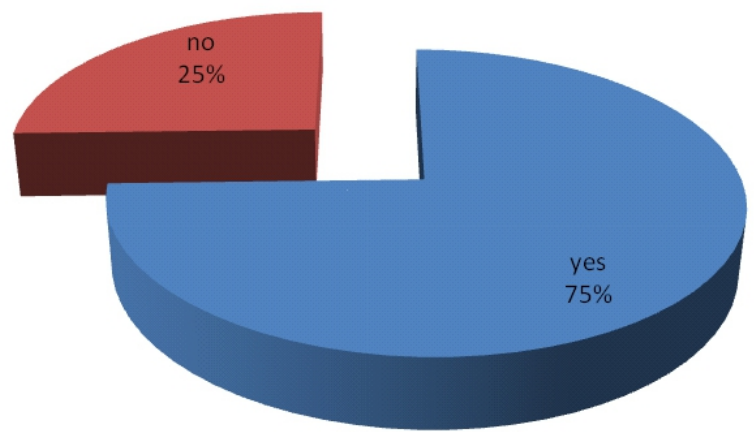

Source: Survey Data (2015)

\section{Child performance}

The performance of respondents children were summarised in figure 4. Results of the research show that $19(6 \%)$ of the children performed excellently as reported by their parents, 185 (62\%) had an average performance, $52(18 \%)$ had a performance of below average while the remaining parents $43(14 \%)$ were not aware of the performance of their children in school. The results show that a majority of the parents confirmed that their children performed averagely in class.

Figure 4 Child Performance

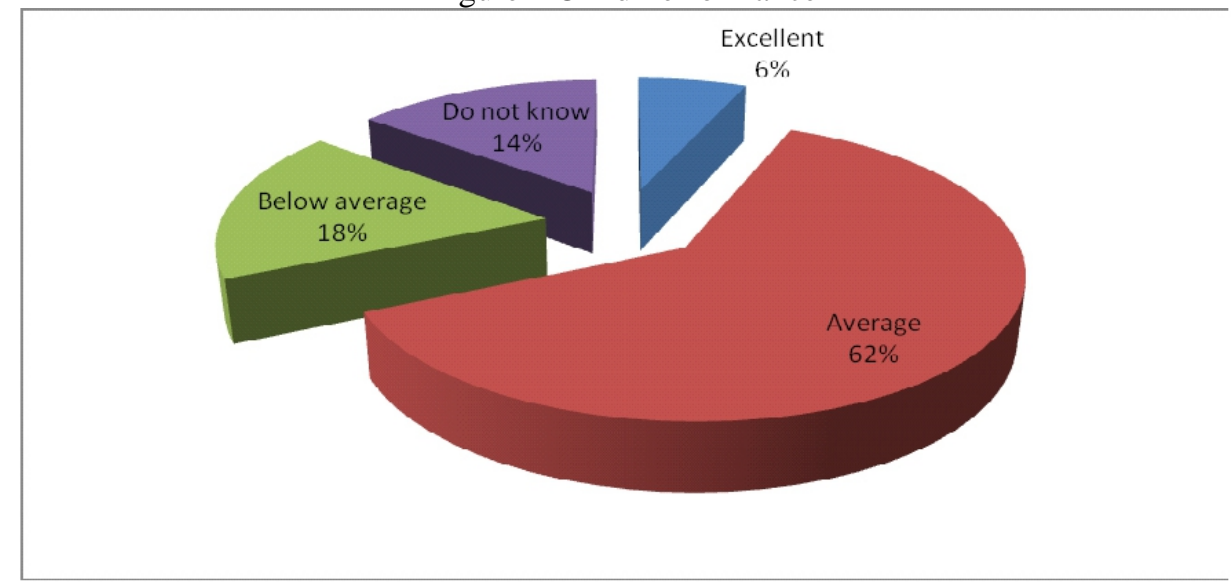

Source: Survey Data (2015)

\section{Parental Involvement in Their Children Education}

The success of any education programme requires the participation of both parties which comprise of the counselor and the intended counselee; 
other stakeholders crucial for this success include parents and religious institutions as envisaged in the KESSP (2005-2010).

\section{Influence of parental income on learner retention}

The first objective of the research sought to establish the influence of parental income on learner retentention. Respondents were asked to rate the impact of aspects of parental income on learner retention using a five point Likert rating scale that was provided in the questionnaire. The findings were tabulated in Tables 6 to Table 12 which showed per indicator ratings of the impact of the aspects of income on learner retention.

Table 6 I provide my child with necessary stationery for learning

\begin{tabular}{llcccc} 
& & Frequency & Percent & \multicolumn{2}{c}{ Mean } \\
\hline & Strongly agree & 38 & \multicolumn{2}{c}{13} & \\
& Agree & 101 & 34 & \\
& Strongly disagree & 84 & 28 & \\
& Disagree & 41 & 14 & \\
\multirow{2}{*}{ Total } & Neutral & 35 & 11 & \\
& & 299 & 100 & 59.8 \\
\hline
\end{tabular}

Source: Survey Data (2015)

\section{Provision of children with necessary stationery for learning.}

In terms of provision of necessary stationery for learning by parents the study found that $13 \%$ of the parents strongly agreed, 34\% agreed, 28\% strongly disagreed, $14 \%$ disagreed while the remaining $11 \%$ were neutral as shown in Table 6. These findings show that most parents disagree with this statement which indicates that most parents do not buy their children necessary stationery for study. This is supported by the findings in Table 4 which show that $32 \%$ of the parents earn an income of less than Ksh. 10,000.

\section{Provision of Learners with personal text books}

Table 7 show parents response on whether they provide their children with personal text books. $10 \%$ of the parents strongly agreed to this opinion, 29\% agreed, 31\% strongly disagreed, 21\% disagree while 9\% were neutral. Findings show that most of the parents 52\% disagreed with this opinon meaning that they do not buy their children personal txt books. These findings agree with Greg (2008) that the level of family income influences students' retention because it determines the availability of education material or lack of it and availability of school fees or lack of it. 
Table 7 I buy my child personal text books

\begin{tabular}{lcccc} 
& & Frequency & Percent & Mean \\
\hline \hline \multirow{4}{*}{ Strongly disagree } & 30 & 10 & \\
\multirow{4}{*}{ Total } & Agrongiy agree & 87 & 29 & \\
& Disagree & 93 & 31 & \\
& Neutral & 61 & 21 & \\
& & 28 & 9 & \\
& & 299 & 100 & 59.8 \\
\hline \hline
\end{tabular}

\section{Provision of confortable study chair and table at home.}

In terms of provision of a comfortable study chair and table for study at home the study established that $7 \%$ of the strongly agreed, $38 \%$ agreed, $35 \%$ strongly disagreed, $14 \%$ disagreed while $6 \%$ were neutral as shown in Table 8. The findings show that most parents $49 \%$ disagree that parents provide their children with a comfortable study chair and table at home. These findings conform to Kimu, (2012) that in some homes of the poor, there might be no table and chairs that can be used for reading, while light for night studies is either of very poor quality or non-existent, thus the family environment is not conducive to learning.

Table 8 I have provided my child with a comfortable study chair and table

$$
\text { Frequency }
$$

Percent

Mean

\begin{tabular}{llccc}
\hline & Strongly agree & 21 & 7 & \\
& Agree & 115 & 38 & \\
& Strongly disagree & 105 & 35 & \\
& Disagree & 41 & 14 & \\
\multirow{2}{*}{ Total } & Neutral & 17 & 6 & \multirow{2}{*}{59.8} \\
& & 299 & 100 & \\
\hline
\end{tabular}

\section{Parents do not Assign their children other duties at home apart from study}

Table 9 show that $8 \%$ of the respondents strongly agreed with this statement, $43 \%$ agreed, $20 \%$ strongly disagreed, $24 \%$ disagreed while $5 \%$ were neutral. The findings show that majority of the parents (51\%) do not assign their children other duties at home apart from study. The findings also show that $49 \%$ of the parents assign their children other duties at home apart from study. This conforms with Republic of kenya (2001) that child labour is rampart practice that continues to keep children out school, especially in the prevailing situation of poverty at the householdlevel. 
Table 9 I do not assign my children other duties apart from study Frequency Percent Mean

\begin{tabular}{llcccc}
\hline & Strongly agree & 23 & 8 & \\
& Agree & 127 & 43 & \\
& Strongly disagree & 61 & 20 & \\
& Disagree & 73 & 24 & \\
& Neutral & 15 & 5 & \\
Total & & 299 & 100 & 59.8 \\
\hline & & Source: Survey Data(2015)
\end{tabular}

\section{Visit to school to enquire about the Learners Progress}

In relation to whether parents visit school regularly to enquire about the progress of their children, the study established that $32 \%$ of the parents strongly agreed to this opinion, 43\% agreed, 19\% strongly disagreed, 4\% disagreed while $2 \%$ were neutral this is shown in Table 10 . The findings show that majority of the parents (75\%) visit school regularly to enquire the progress of their children while $24 \%$ do not. These findings are in agreement with those of Lemmer (2007) that the frequency of parent-teacher contact influences the participation of learners in learning and thereby improve their retention in school.

Table 10I visit school regularly to enquire about the progress of my child Frequency Percent

Mean

\begin{tabular}{llcrll}
\hline & Strongly agree & 94 & 32 & \\
& Agree & 129 & 43 & \\
& Strongly disagree & 58 & 19 & \\
& Agree & 11 & 4 & \\
& Neutral & 7 & 2 & \\
Total & & 299 & 100 & 59.8 \\
\hline
\end{tabular}

Source: Survey Data (2015)

\section{Parents buy children presents whenever they do well}

Table 11 show that 5\% of the parents strongly agree that they buy their children presents whenever they do well at school, 50\% agree, $18 \%$ strongly disagree, $24 \%$ disagree while $3 \%$ were neutral. The findings show that majority of the parents 55\% agreed to have motivated their children whenever they did well at school while $42 \%$ disagreed. These findings are confirmed by the findings of Table 4 that majority of the parents know the performance of their children while $14 \%$ of them were not aware of the performance of their children. 
Table 11I buy child presents whenever he does well at school Frequency

Percent

Strongly agree

Agree

Strongly diagree

Disagree

Neutral

Total

16

149

53

73

8

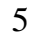

50

18

24

3

10059.8

Source: Survey Data (2015)

\section{Parents encourage Children to work hard and Respect teachers}

In regards parents encouraging children to work hard and respect their parents, the study found that, $1 \%$ of the parents strongly agreed, $18 \%$ agreed, $51 \%$ strongly disagreed, $29 \%$ diasagreed while $2 \%$ were neutral Table 12. This shows that majority of the parents $80 \%$ do not motivate their children their to work hard and respect their teachers. These findings in agreement to to Kari (2011) that minority students with parents from traditional communities may be at a disadvantage because parents and schools have different ideas about responsibility.

Table 12I encourage my child to work hard and respect his teachers

\section{Frequency}

Strongly agree

Agree

Strongly disagree

Disagree

Neutral

Total
Percent

Mean

\begin{tabular}{llccc}
\hline & Strongly agree & 3 & 1 & \\
& Agree & 53 & 18 & \\
& Strongly disagree & 153 & 51 & \\
& Disagree & 83 & 29 & \\
\multirow{2}{*}{ Total } & Neutral & 7 & 2 & \\
& & 299 & 100 & 59.8 \\
\hline
\end{tabular}

Source: Survey Data (2015)

\section{Discipline on Learners' Retention}

The study found that indiscipline was a significant factor towards learner dropout rates. This involved truancy, irresponsible sexual behavior in form of early pregnancies and prostitution because of high numbers of tourists found in this area of Central zone of Malindi sub-county, Kenya. The researcher found that the boda boda business had also impacted negatively on education in this area.

\section{Parent interest on child learning}

Table 13 shows that $14 \%$ of the respondents strongly agree that parents lack interest on child's learning, 37\% agree, 12\% strongly disagree, $28 \%$ disagree while $9 \%$ were neutral. The findings show that majority of the 
parents have interest on their child learning. These findings are in agreement with 1995 primary census, MOEST (1998) that the commonest reason for dropping out of school is lack of interest on the part of parents owing to their own illiteracy. Parents have a negative attitude towards education for they do not see the immediate benefit.

Table 13Lack of interest of parent on child learning

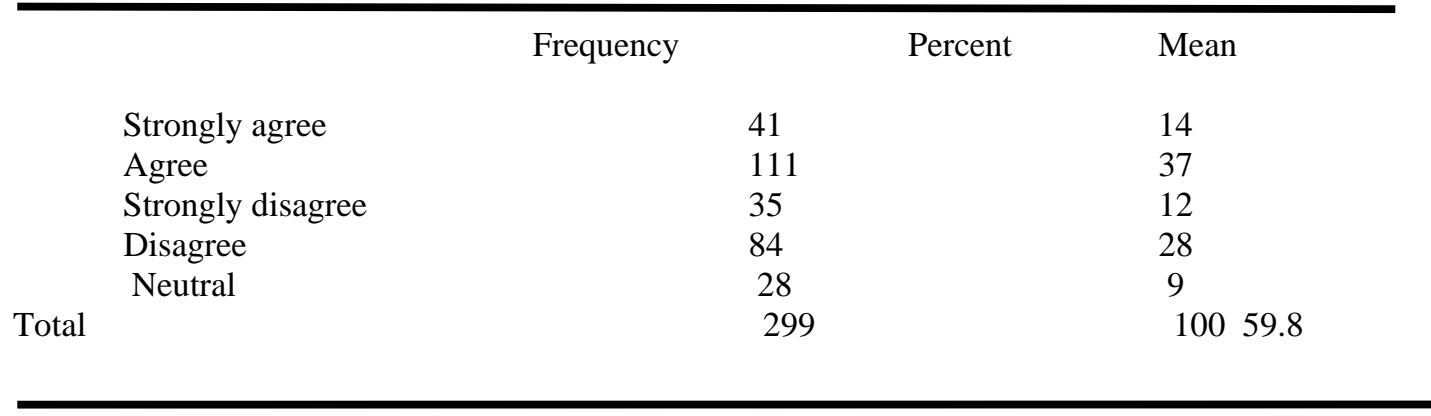

Source: Survey Data (2015)

\section{Attendance of academic clinics by Parents}

In regards to lack of interest by parents to attend academic clinics, $20 \%$ of the parents strongly agreed it had a great influence on learner retention, 37\% agreed, 12\% strongly disagreed, $28 \%$ disagreed and the remaining 9\% were neutral Table 14 . The findings show that majority of the parents agree to this statement while $42 \%$ of them disagree. The findings are in agreement with Simiyu, (2012) that childrens whose parents were involved in school activity had higher chances of completing a primary course compared to those parents whose parents never participated in school activities.

Table 14Lack of interest by parents to attend academic clinics

\begin{tabular}{clccc}
\hline & Frequency & Percent & \multicolumn{2}{c}{ Mean } \\
& Strongly agree & 61 & 20 & \\
& Agree & 97 & 33 & \\
& Strongly disagree & 28 & 9 & \\
& Disagree & 99 & 33 & \\
\multirow{2}{*}{ Total } & Neutral & 14 & 5 & 59.8 \\
\hline
\end{tabular}

Source: Survey Data (2015)

\section{Parent supervise pupil school work at home}

Table 15 show that $14 \%$ parents strongly agree that failure by parents to supervise pupils learning at home greatly influence learner retention, $42 \%$ agree, 9\% strongly disagree, 29\% disagree while 6\% were neutral. The findings show that majority of the parents $56 \%$ agree that parent supervision 
of pupil learning at home important. The findings are in agreement with Susan, (2010) that students whose parents monitor and regulate their activities, provide emotional support, encourage independent decision making and are generally more involved in their schooling are less likely to drop out of school.

Table 15Failure by to supervise pupil learning at home Frequency

Percent

Mean

\begin{tabular}{lcc}
\hline Strongly agree & 41 & 14 \\
Agree & 125 & 42 \\
Strongly disagree & 27 & 9 \\
Disagree & 87 & 29 \\
Neutral & 19 & 6 \\
Tetal & 200 & $100-509$ \\
\hline
\end{tabular}

Source: Survey Data (2015)

\section{Parent support to the Administration}

The study established that $24 \%$ of the parents strongly agreed to this statement, 36\% agreed, 5\% strongly disagreed, 31\% disagreed and $4 \%$ were neutral as shown in Table 16. The research shows that most of the parents supported this statement. The researcher found out that parents were not aware whether had a right to support the administration in both in kind and opinions. These findings are in agreement with Kari, (2011), who found out that minority students with parents from traditional communities may be at a disadvantage because parents and schools have different ideas about responsibility.

Table 16Failure by to Support Administration in learner Discipline

\begin{tabular}{lrcrl}
\hline & Frequency & Percent & Mean \\
Strongly agree & 73 & 24 & \\
Agree & 107 & 36 & \\
Strongly disagree & 15 & 5 & \\
Disagree & 91 & 31 & \\
Neutral & 13 & 4 & \\
Total & 299 & & 100 & 59.8 \\
\hline
\end{tabular}

\section{Parents monitor pupil class attendance}

In regard to failure by parents to monitor learner class attendance, the research established that $4 \%$ of the parents strongly agreed that failure to monitor pupil class attendance greatly influence learner retention, 34\% agreed, $2 \%$ strongly disagreed, $42 \%$ disagreed and $18 \%$ were neutral Table 17. 
Table 17Failure by parents to monitor pupils attendance of classes

\begin{tabular}{|c|c|c|c|}
\hline & Frequency & Percent & Mean \\
\hline Strongly agree & 11 & 4 & \\
\hline Agree & 101 & 34 & \\
\hline Strongly disagree & 8 & 2 & \\
\hline Disagree & 125 & 42 & \\
\hline Neutral & 54 & 18 & \\
\hline Total & 299 & 100 & 59.8 \\
\hline
\end{tabular}

Source: Survey Data (2015)

\section{Parents notify administration in case of absenteeism}

According to the International Labour Organization (2010) Absenteeism in secondary school was however much lower than in primary school further indicating that that boys miss school more than girls. The study sought to find out if parents were involved in dealing with their children absenteeism in school. The study findings show that majority $40 \%$ of the respondents cited agree. 23\% strongly agreed, 3\% strongly disagreed, $32 \%$ disagreed while $2 \%$ were neutral as depicted in Table 18 . This implies that parents report cases of absenteeism which would impact positively on the retention of the student. Quantitative research indicates that sickness and schooling costs claim up to $75 \%$ of reasons for absenteeism in primary schools, Malindi sub-county education subsector statistical returns, (2013). In-depth data reveal that children miss school also due to lack of strictness and proper monitoring in schools.

Table 18Parents notify administration in case of absenteeism

\begin{tabular}{ccccc}
\hline & Frequency & Percent & \multicolumn{2}{c}{ Mean } \\
& Strongly agree & 68 & 23 & \\
& Agree & 119 & 40 & \\
& Strongly disagree & 9 & 3 & \\
& Disagree & 97 & 32 & \\
& Neutral & 6 & 2 & \\
Total & & 299 & 100 & 59.8 \\
\hline
\end{tabular}

Source: Source Survey Data (2015)

\section{Motivating learners to work hard}

According to 1995 primary census, MOEST (1998) that the commonest reason for dropping out of school is lack of interest on the part of parents owing to their own illiteracy. Parents have a negative attitude towards education for they do not see the immediate benefit. The research shows that $28 \%$ of parents strongly agree that failure by parents to motivate learners greatly influence learner retention, $18 \%$ agree, $2 \%$ strongly disagree, $51 \%$ disagree while $1 \%$ were neutral. This shows that majority of the parents 
do not concur that failure to motivate learners to work hard can in influence their retention in school. These findings are in agreement with Haveman \& Wolfe, (2005) that parents with higher educational level could motivate the intellectual potential within children that may lead them to perform better in school and return strive for further education.

Table 19Failure by parents to motivate learner to work hard

\begin{tabular}{llccc} 
& & Prequency & Percent & Mean \\
\hline & Strongly agree & 83 & 28 & \\
& Agree & 53 & 18 & \\
& Strongly disagree & 8 & 2 & \\
& Disagree & 152 & 51 & \\
Total & Neutral & 3 & 1 & $\mathbf{5 9 . 8}$ \\
\hline
\end{tabular}

Source: Survey Data (2015)

\section{Education on Retention}

In regards the level of education of the parent, the researcher established that majority of the respondents $40 \%$ (PhD) and 36\% (Masters) cited high education levels to have a great influence on learner retention, similarly a majority of the respondents $45 \%$ (Secondary) and 51\% (Primary) cited low education levels also to have a great influence on learner retention.

Table 20 Influence of Parent Level of Education on Learner Retention

Key; SA- strongly agree, A- agree, SD- strongly disagree, D- disagree, N- neutral

\begin{tabular}{llllllr}
\hline Education level of parent & SA & A & SD & D & N & percent \\
PhD & 40 & 7 & 12 & 35 & 6 & 100 \\
Masters & 36 & 17 & 9 & 37 & 1 & 100 \\
Degree & 43 & 19 & 7 & 26 & 5 & 100 \\
Diploma & 39 & 6 & 37 & 4 & 14 & 100 \\
P1 & 39 & 5 & 31 & 24 & 1 & 100 \\
Secondary & 45 & 10 & 9 & 33 & 3 & 100 \\
Primary & 51 & 18 & 2 & 28 & 1 & 100 \\
\hline
\end{tabular}

Source: Survey Data (2014)

These findings are in agreement with Otunge (2004) that children who played truant or dropped out of school belonged to not only economically poor families but also to the parents with little formal education. Kimu, (2012) concurs with this when he says parents' attitudes and involvement towards their children's learning vary according to educational level. The research established that educated parents tend to motivate their children in matters related to schooling and support them academically. The findings also concur with the 1995 primary census, MOEST (1998) that the commonest reason for dropping out of school is lack of interest on the part of parents owing to their own illiteracy. 


\section{Learner Retention}

The researcher summarized the responses for the rate of learner drop out in the first, second, third, fourth, fifth, sixth and seventh years of study. As shown in Table 21, a majority of the respondents rated dropout rates for years one, two, three, four, five and six at $21-30 \%$. On the contrary majority of the respondents cited low dropout rates in the seventh year at the rate 1$10 \%$. These findings show that dropout rates are high in the lower grades.

Table 21Rate of Learner Dropout

KEY: $1=$ None (0\%), 2= 1-10 (\%), 3=11-20 (\%), 4= 21-30\% and 5=Over 40 (\%)

\begin{tabular}{|c|c|c|c|c|c|c|c|}
\hline \multicolumn{2}{|c|}{ Dropout rate(\%) } & $2^{\text {nd }}$ & $3^{\mathrm{rd}} \mathrm{yr}$ & $4^{\text {th }} \mathrm{yr}$ & $5^{\text {th }} \mathrm{yr}$ & $6^{\text {th }} y r \quad 7^{\text {th }} y$ & \\
\hline None & 8 & 3 & 4 & 4 & 16 & 2 & 1 \\
\hline $1-10 \%$ & 28 & 33 & 29 & 31 & 42 & 32 & 51 \\
\hline $11-20 \%$ & 12 & 9 & 9 & 5 & 3 & 3 & 2 \\
\hline $21-30 \%$ & 37 & 33 & 42 & 36 & 34 & 40 & 18 \\
\hline Over 30\% & 15 & 22 & 16 & 24 & 5 & 23 & 28 \\
\hline Total & 100 & 100 & 100 & 100 & 100 & 100 & 100 \\
\hline
\end{tabular}

The research found that high wastages observed in year 1,2,3,4,5 and year 6 are mostly due to grade repetition indicated on the findings in question 5 (which other factors influence learner retention in your school?). The other factors cited in this question are poverty and early pregnancies. These findings are in agreement with Republic of Kenya, (2001) that child labour is a rampant practice that continues to keep children out of school, especially in the prevailing situation of poverty at household level.

\section{Parental Contribution on Learner Retention}

The study conducted a multiple regression analysis to examine the effect of income, discipline and education on learner retention in Central zone of Malindi sub-county, Kenya. The results were as presented in Table 22, 23 and 24 below.

Table 22Parental Contribution on Learner Retention as per Regression Model

\begin{tabular}{|c|c|c|c|c|}
\hline \multirow{2}{*}{$\begin{array}{l}\text { Model } \\
\qquad 1\end{array}$} & \multicolumn{2}{|c|}{ R Square } & \multirow{2}{*}{$\begin{array}{c}\text { Adjusted R } \\
\text { R Square } \\
.936\end{array}$} & \multirow{2}{*}{$\begin{array}{l}\text { Standard error of the } \\
\text { estimate } \\
\qquad .4522670\end{array}$} \\
\hline & $.992^{\mathrm{a}}$ & .984 & & \\
\hline
\end{tabular}


Table 23Parental Contribution on Learner Retention as per Regression Model ANOVA

\begin{tabular}{|c|c|c|c|c|}
\hline Model & Sum of Squares & $\begin{array}{l}\text { A } \\
\text { df }\end{array}$ & Mean of Square & Sig \\
\hline 1 Regression & 12.595 & $\begin{array}{c}3 \\
.161\end{array}$ & 4.198 & 20.526 \\
\hline $\begin{array}{l}\text { Residual } \\
\text { Total }\end{array}$ & $\begin{array}{l}.205 \\
12.800\end{array}$ & $\begin{array}{l}1 \\
4\end{array}$ & .205 & \\
\hline
\end{tabular}

a Dependent Variable: learner retention

$b$ Predictors: (Constant), parental income, discipline on learners and education level

Table 24 Regression Analysis Results

Model Unstandardised coefficients Standardised coefficients t Sig

\begin{tabular}{lcccccc}
\hline & \multicolumn{2}{c}{ B } & \multicolumn{2}{c}{ Std error } & Beta & \\
1 Constant & 1.670 & .694 & & 2.405 & .251 \\
Education & 1.375 & .253 & 1.166 & 5.439 & .116 \\
Income & .011 & .213 & .012 & .053 & .966 \\
Discipline & -1.750 & .506 & -.536 & -3.461 & .179 \\
\hline
\end{tabular}

Dependent Variable: learner retention in public primary schools.

The regression equation $\left(Y=\beta_{0}+\beta_{1} X_{1}+\beta_{2} X_{2}+\beta_{3} X_{3}+\varepsilon\right)$ was: $\mathrm{Y}=1.670+1.166 \mathrm{X}_{1}+0.012 \mathrm{X}_{2}-0.536 \mathrm{X}_{3}$.

The results indicated that there was significant relationship between parental level of education ( $p=0.116$ ) and learner retention. The findings indicated that there was no significant relationship ( $\mathrm{p}=0.966$ ) between income level of parent and learner retention. The findings also indicated that there was significant relationship ( $p=0.179$ ) between parental involvement in learner discipline and learner retention. In assessing the regression model for parental involvement as per the indicators in the study, the study evaluated the standardized coefficients of the study and illustrated the results as indicated in the regression equation below.

$$
\begin{gathered}
\mathrm{Y}=1.670+1.166 \mathrm{X}_{1}+0.012 \mathrm{X}_{2}-0.536 \mathrm{X}_{3} \\
\text { Standard error } 0.694
\end{gathered}
$$

The regression equation established, taking all factors into account (level of parental income, learner discipline education) constant at zero learner retention will be 1.670 . These findings show a significant increase in the level of education will lead to an improvement in learner retention by a factor of 1.166. In regard to level of income; a unit increase income levels of the parent will lead to an improvement in learner retention by a factor of 0.012. In regard to discipline; a unit increase in parental involvement in learner discipline would lead to an improvement in learner retention by a factor of 0.536 . The results indicated that parental level of education was the most dominant factor influencing learner retention. The findings agree with 
Haveman \& Wolfe (2005) that parents with higher educational level could motivate the intellectual potential within their children that may lead them to perform better in school and return the strive for further education. These findings are also in line with the 1995 primary census, that the commonest reason for dropping out of school is lack of interest on the part of parents owing to their own illiteracy (MOEST, 1998).

\section{Conclusion}

The study concludes that income, discipline and education influence learner retention in public primary schools of central zone of Malindi subcounty, Kenya. The regression analysis indicates education is a significant factor influencing learner retention in public primary schools, followed by discipline and income level of parents. The study concludes that tourism, bodaboda, poverty, illiteracy, repetition as serious issues affecting learner retention in central zone of Malindi sub-county, Kenya. The study also concludes that government allocation to free primary education be increased in order to relieve parents the burden of paying extra levies for classroom construction. Adult learning centres should also be put up in this area in order to boost adult literacy levels.

\section{References:}

Anderson, K.J and Minke, K.M. 2007. Parental involvement in education:towards an understanding of parents' decision-making. Jounal of educational research, 100(5);311- 323.

Anorld, L.A., Newman, J.H., Gaddy,B.B. \& Dean, C.B. 2006. A look at the conditions of rural education research:setting a new direction for future research. Journal of research in education, 20 (6):1-43, http://www.umaine.edu/drre/206html, 10May2014.

Buote, C. A. 2001. Relations of autonomy and relatedness to school functioning and relatedness to school functioning and psychological adjustment during adolescence. Journal of Humanities and Social Sciences, 62 (1).

Bridgemohan, R.R.2002. Parent involvement in early childhood in Kwa-Zulu Natal. PhD Thesis. Johannesburg: University of South Africa.

Brophy J. (2006). Grade Repetition, UNESCO-IIEP Education Policy Series, V. 6.

Coleman, J.S (2000). Families and Schools Educational Research.M.Ed Thesis. Johannesbourg: University of South Africa.

Cooper, H.2007. The battle over homework: Common ground for administrators, teachers and

parents. Thousand Oaks, C.A: Cowin. 
Desforges, C. \& Abouchaar, A. 2003. The impact of parent involvement, parental support and family education on pupil achievement and adjustment: A review of literature, www.dcsf.gov,uk/research/rb433.doc, 17 April 2014. European Commission (2001), European report on quality of school education: sixteen quality Indicators may 2000. Luxembourg: office for official publications of the European Communities.

Friendman, T.L. 2011. We need better parents. New York times, Sunday review, November 21 www.nytimes.com/2011/20/opinion/Sunday/friedmanhowabout-better-parents. 14 April. 2014.

Gordon, D. \& Lance L. (2005). The impact of family income on child achievement, http://www.aifsgov.aulinst, $22^{\text {nd }}$ May 2014

Greg. J.D (2008). Income and child wellbeing. http://www.esriell/pdf. $22^{\text {nd }}$ May 2014

Hung, C-L. 2007. Family, schools and Taiwanese childrens' outcomes. Educational research, 49 (2):115-125.

Johnson, B. \& Christensen, L. 2006. Educational research, qualitative and mixed approaches. ( ${ }^{\text {nd }}$ Ed.). Boston: Allyn Bacon.

Kari. S. (2011). I buy paraffin so he can read in the evening-a study in kenya about parental involvement in school,

http://www.ernape.net/ejournal/endex.php/jpe/article/view. 24 ${ }^{\text {th }}$ April

2014

Kimu, A.M (2012). Parent involvement in public primary schools in Kenya. Unpublished Thesis. University of South Africa.

Kgaffe, M.M. (2001). Barriers to parent involvement in rural communities in North West Province. M.Ed Thesis. Johannesbourg: University of South Africa.

Lemmer, E.N. (2007). Parent involvement in teacher education in South Africa, International Journal about parents in education, 1(1):218-229.

Ministry of Education (2012). Task force on The Re-Alignment of the Education Sector to the Constitution of Kenya2010. Government Printers, Nairobi, Kenya.

Miron, J.M. 2004. La dificile reconnaissance de" lexpertise parentale”. Recherché et Formation, (47):55-68.

Muhoho, G." Universal Free Education: the experience" Paper presented at the association of Teachers of Africa Teachers'. Nairobi 2005.

Mugenda O. M., and Mugenda A. G., (2003). Research Methods: Quantitative and qualitative Approaches: African Centre for Technology Studies (ACTS), Nairobi Kenya.

Naidoo, J.P. 2005. Educational decentralization and school governance: From policy to practice. International institute for Educational Planning 7-9 rue Eugene Delacroix, 75116, Paris: UNESCO.1997. 
Nzyima M.P. (2011). Relationship between parental involvement in children education and their academic performance in public primary schools in Dagoretti District. M.Ed project Nairobi: University of Nairobi.

Pamela E.D. ( 2005). The indirect role of parental expectations and the home environment. University of Michigan;

http://ww.mikemcmahon.info/parenteducationincome.pdf. 22 ${ }^{\text {nd }}$ May 2014

Saiduddin, J. (2003). Factors Affecting Achievement at Junior High School on the Pine Ridge Reservation. Spain: Ohio State University.

Suresh K.N.U (2010). Parental involvement in Children's education. Does parents education level really matter? European journal of social sciencesvolume 16, number 3 (2010).

Susan, E.M. (2010). Revisiting an old question; how much does parental affect child outcome. http://www.esriel/pdf.17 ${ }^{\text {th }}$ May 2014.

UNESCO (2000). Reducing repetition: Issues and Strategies. Paris :UNESCO office. 